\title{
YIELD AND FEED VALUE OF MAIZE (ZEA MAYS L.) GREEN FORAGE OBTAINED FROM EUROPEAN CULTIVARS GROWN IN POLAND
}

\author{
GĄSIOROWSKA, B. - PŁAZA, A. - RZĄŻEWSKA, E. - WARANICA, M. \\ Agrotechnology Department, Faculty of Natural Sciences, Siedlce University of Natural \\ Sciences and Humanities, Poland \\ (e-mail: anna.plaza@uph.edu.pl; barbara.gasiorowska@uph.edu.pl; \\ emilia.rzazewska@uph.edu.pl; szur@uph.edu.pl) \\ Corresponding author \\ e-mail: emilia.rzazewska@uph.edu.pl
}

(Received 29 $9^{\text {th }}$ Mar 2019; accepted $13^{\text {th }}$ Jun 2019)

\begin{abstract}
This article presents the results of a research conducted to evaluate the production-related value and feeding value of selected maize (Zea mays L.) cultivars included in the Common Catalogue of Varieties of Agricultural Plant Species (CCA). The following two factors were examined: A - the harvest date of maize green matter (I - tasseling stage ( $75 \%$ of plants at this stage), II - milk maturity stage (after three weeks), III - wax maturity stage (after another three weeks)); B - cultivars with different times of maturity (Pyroxenia - very early, FAO 130, Codimi - early FAO 200, Moschus - early, FAO 220, Alombo - medium early, FAO 230, Celive - medium early, FAO 245). The results demonstrated that the highest dry matter yield was produced by plants at the wax maturity stage. $\mathrm{Cv}$. Alombo had the highest fresh matter yield. The highest organic matter (OM) digestibility and dry matter (DM) digestibility were determined for maize plants harvested at the wax maturity stage. The earliest maturing cultivars, namely Pyroxenia and Codimi, had the highest organic matter (OM) digestibility and dry matter (DM) digestibility. The highest total protein content and crude ash were recorded for maize plants harvested at the tasseling stage. $\mathrm{Cv}$. Codimi, Moschus, Alombo and Clive produced the highest concentrations of these components.
\end{abstract}

Keywords: dry matter yield, green forage chemical composition, organic matter (OM) digestibility, dry matter (DM) digestibility

\section{Introduction}

Soil and climatic conditions of Poland are optimal for the cultivation of maize for silage (Ptaszyńska and Sulewska, 2008). The species represents the most productive fodder crops (Strzetelski et al., 2001; Brzóska, 2001). Harvest date and cultivar selection determine the crop plant make-up and structure, which may lead to substantial differences in yielding, chemical composition and feed value of maize plants (Kowalik, 2001).

As the area under maize production and economic role of maize are on the increase, there is growing demand for better and better cultivars and thus hybrids (Korniewicz et al., 2000; Sulewska et al., 2011). Jha et al. (1998) and Adamczyk (2001) emphasized the fact that the role of new cultivars in modern agriculture is of great importance.

The following factors affect the quality and quantity of harvested yields: agrotechnology (40\%), climatic conditions (30\%), selected cultivars (30\%). Thus, a third of the effect is cultivar-related (Sulewska et al., 2011). As a result, it seems reasonable to examine selected cultivars from other Europeans countries, such as Germany, the Czech Republic, Slovakia and France, in terms of their suitability for cultivation in Poland. The objective of the study was to evaluate the production-related 
value and feed value of selected cultivars included in the Common Catalogue of Varieties of Agricultural Plant Species (CCA) harvested at various development stages, which were used as raw materials for the production of whole plant silage from maize cultivated under the soil and climatic conditions of Poland.

\section{Materials and methods}

Field research was conducted in 2009-2011 on a private holding located in Kowiesy near Siedlce (52 $03^{\prime} 39^{\prime \prime}$ N, $22^{\circ} 33^{\prime} 80^{\prime}$ ' E). The experiment was carried out on the soil classified as Albic Luvisol (Arenic) characterised by a slightly acid reaction and average available phosphorus, potassium and magnesium contents. Its humus content was $1.28 \%$. The trial was a split-plot arrangement with three replicates. The following two factors were investigated: A - maize green matter harvest date ( $\mathrm{I}$ - tasseling stage $(75 \%$ of plants at this stage), II - milk maturity stage (after three weeks), III - wax maturity stage (after another three weeks)); B - cultivars with different earliness of maturity (Pyroxenia - very early FAO 130, Codimi - early FAO 200, Moschus - early FAO 220, Alombo - medium early FAO 230, Celive - medium early FAO 245).

The number of plants per 1 metre was 10, and the sowing rate was established based on previous research by Sulewska (2001). Maize was grown as a continuous crop. Cattle manure was applied at the rate of 30 tha $^{-1}$ in the autumn. In spring, phosphorus and potassium fertilisers were applied at rates matching soil contents of available elements, that is $60 \mathrm{~kg} \mathrm{Pha}^{-1}$ and $90 \mathrm{~kg} \mathrm{Kha}^{-1}$. Nitrogen fertiliser was applied pre-plant at the rate of $92 \mathrm{~kg} \mathrm{Nha}^{-1}$ in the spring and followed by maize, the nitrogen rate being increased due to an application of Polifoska 6. Maize cultivars were planted in late April. The green matter of maize crop was harvested at three dates as set in the methodology. During harvest, the fresh matter yield of whole plants was determined in each plot, and their average samples were taken for chemical analyses. Dry matter content, total protein content, crude ash content, organic matter digestibility and dry matter digestibility were determined in the sampled material by means of near infrared spectroscopy (NIRS) using the spectrometer NIR Flex N-500.

The results of the study were statistically analysed; ANOVA following the linear model for a two factor split-plot design was performed for each trait examined, and separation of means was obtained by means of Tukey test at the significance level of 0.05 .

\section{Results and discussion}

\section{The dry matter yield of maize plants}

The dry matter yield of maize plants was significantly affected by the experimental factors and their interaction (Table 1).

The highest dry matter yield was produced by maize plants harvested at the wax maturity stage. In corresponds to findings reported by Toler et al. (1998), Kowalik (2001), Michalski (2002), Filya (2004), Szempliński et al. (2009), Lynch et al. (2012), Magalhäes et al. (2015) and Komainda et al. (2018). In the study discussed here, the dry matter yield of maize plants harvested at the milk stage was lower, it being the lowest when harvest was performed at the tasseling stage. It may be explained by the fact that the dry matter yield of maize plants increases from the tasseling stage to the wax 
maturity stage. In the experiment reported here, the highest dry matter of maize plants was produced by the medium early cultivar Alombo, the yields of the maize plants of cv. Pyroxenia, Codimi, Moschus and Celive being significantly lower. Also Sulewska and Koziary (2005), Podkówka et al. (2015), Swanckaert et al. (2016) and Nawab et al. (2017) reported a higher yielding potential of later maturing cultivars. In the current study, an interaction between the experimental factors was confirmed indicating that the highest dry matter yields were supplied by the following cultivars: Pyroxenia, Codimi, Moschus, Alombo and Celive harvested at the wax maturity stage, it being the lowest for all the experimental cultivars harvested at the tasseling stage.

Table 1. Dry matter yield of maize plants (means across 2009-2011), tha ${ }^{-1}$

\begin{tabular}{|c|c|c|c|c|}
\hline \multirow{2}{*}{ Cultivars (B) } & \multicolumn{3}{|c|}{ Harvest date (A) } & \multirow{2}{*}{ Means } \\
\hline & I & II & III & \\
\hline Pyroxenia & 6.59 & 13.89 & 18.04 & 12.84 \\
\hline Codami & 7.11 & 12.74 & 19.68 & 13.18 \\
\hline Moschus & 6.57 & 15.06 & 20.26 & 13.97 \\
\hline Alombo & 7.98 & 15.95 & 23.11 & 15.68 \\
\hline Celive & 7.10 & 13.82 & 21.08 & 14.00 \\
\hline Means & 7.07 & 14.29 & 20.43 & - \\
\hline ANOVA & \multicolumn{2}{|c|}{$\mathrm{P}$-value } & \multicolumn{2}{|c|}{$\mathrm{LSD}_{0.05}$} \\
\hline Harvest date (A) & \multicolumn{2}{|c|}{$<0.001$} & \multicolumn{2}{|c|}{3.63} \\
\hline Cultivars (B) & \multicolumn{2}{|c|}{$<0.001$} & \multicolumn{2}{|c|}{1.32} \\
\hline Interaction $(\mathrm{AxB})$ & \multicolumn{2}{|c|}{$<0.001$} & \multicolumn{2}{|c|}{5.40} \\
\hline
\end{tabular}

\section{The total protein content in plants}

Statistical analysis demonstrated a significant influence of the experimental factors and their interaction of total protein content in maize plants (Table 2).

The highest total protein content was recorded for maize plants harvested at the tasseling stage. When delayed the harvest date to the milk maturity stage, a significant decrease of total protein content was recorded for maize plants harvested. When harvest is further delayed to the wax maturity stage, no total protein content significant decrease in maize plants is observed.

Table 2. Total protein content in plants, gkg-1 d.m.

\begin{tabular}{|c|c|c|c|c|}
\hline \multirow{2}{*}{ Cultivars (B) } & \multicolumn{3}{|c|}{ Harvest date (A) } & \multirow{2}{*}{ Means } \\
\hline & I & II & III & \\
\hline Pyroxenia & 100.6 & 82.3 & 78.5 & 87.1 \\
\hline Codami & 108.7 & 83.7 & 80.7 & 91.0 \\
\hline Moschus & 104.9 & 82.1 & 80.4 & 89.1 \\
\hline Alombo & 110.1 & 84.6 & 76.7 & 90.5 \\
\hline Celive & 111.7 & 86.5 & 83.5 & 93.9 \\
\hline Means & 107.2 & 83.9 & 79.9 & - \\
\hline ANOVA & \multicolumn{2}{|c|}{ P-value } & \multicolumn{2}{|c|}{$\mathrm{LSD}_{0.05}$} \\
\hline Harvest date (A) & \multicolumn{2}{|c|}{$<0.001$} & \multicolumn{2}{|c|}{5.9} \\
\hline Cultivars (B) & \multicolumn{2}{|c|}{$<0.001$} & \multicolumn{2}{|c|}{5.2} \\
\hline Interaction (AxB) & \multicolumn{2}{|c|}{$<0.001$} & \multicolumn{2}{|c|}{7.8} \\
\hline
\end{tabular}

It may be explained by fact that the plants harvested in earlier stage are characterized by a higher content of total protein. In corresponds to findings reported by Tolera et al. (1998, 1999), who reported that by delaying the harvest of maize plants, the total 
protein content decreases. However, the regress of total protein in the dry matter of plants at the end of vegetation is low. In the study discussed here, the total protein content of maize plants studied cultivars was on the same level, with the exception of the Pyroxenia cultivar.

The concentration of total protein in plants of this cultivar was significantly lower, which has been confirmed in research by other authors (Tolera et al., 1999; Sulewska, 2001; Schttenhelm, 2008; Podkówka et al., 2015). Špelekovă and Galovă (2018) results of research demonstrated higher protein content in maize cultivars from Europe than from the United States. In the present study reported here, the interaction of the studied factors demonstrated that only in the tasseling stage, the total protein content in maize plants of Pyroxenia cultivar was significantly lower than in the other cultivars. At the milk maturity stage and wax maturity stage, no significant differences were found in the total protein content between the studied cultivars. The highest total protein content was recorded from the Codimi, Moschus, Alombo and Celive maize plants harvested in the tasseling stage, significantly lower from all studied maize cultivars harvested in the wax maturity stage.

\section{The crude ash content in plants}

The content of crude ash in maize plants was significantly differentiated by the experimental factors studied and their interaction (Table 3).

The highest content of crude ash was recorded in maize plants harvested during the tasseling stage. Significantly lower crude ash content was recorded in maize plants harvested at milk maturity stage, the lowest in plants harvested in the wax maturity stage. Also Filya (2004), Yuxiang et al. (2007) and Komainda et al. (2018) demonstrated that by delaying the harvest of maize plants from the stage of early milk to wax maturity stage, the content of crude ash decreases. This should be explained by the fact that plants harvested in earlier stages contain more minerals and more organic components.

Table 3. Crude ash content in plants, gkg-1 d.m.

\begin{tabular}{|c|c|c|c|c|}
\hline \multirow{2}{*}{ Cultivars (B) } & \multicolumn{3}{|c|}{ Harvest date (A) } & \multirow{2}{*}{ Means } \\
\hline & I & II & III & \\
\hline Pyroxenia & 81.3 & 51.2 & 38.8 & 57.1 \\
\hline Codami & 77.6 & 58.8 & 39.9 & 58.8 \\
\hline Moschus & 80.3 & 61.5 & 46.1 & 62.6 \\
\hline Alombo & 83.4 & 61.3 & 42.4 & 62.4 \\
\hline Celive & 81.3 & 60.5 & 45.7 & 62.5 \\
\hline Means & 80.8 & 58.7 & 42.6 & - \\
\hline ANOVA & \multicolumn{2}{|c|}{ P-value } & \multicolumn{2}{|c|}{$\mathrm{LSD}_{0.05}$} \\
\hline Harvest date (A) & \multicolumn{2}{|c|}{$<0.001$} & \multicolumn{2}{|c|}{3.0} \\
\hline Cultivars (B) & \multicolumn{2}{|c|}{$<0.001$} & \multicolumn{2}{|c|}{3.9} \\
\hline Interaction (AxB) & \multicolumn{2}{|c|}{$<0.001$} & \multicolumn{2}{|c|}{5.8} \\
\hline
\end{tabular}

In own studies, also the cultivars significantly differentiated the content of crude ash in plants. Of these, only the plants of maize of the Pyroxenia cultivar had a significantly lower concentration of crude ash than in the plants of the other cultivars. Also, Tolera et al. (1999), Sulewska (2002), Schttenhelm (2008) and Podkówka et al. (2015) demonstrated that cultivars with a longer growing season contained more crude ash both in whole plants and in grain. In the current study, an interaction between the 
experimental factors was confirmed indicating that the highest content of crude ash was recorded in all cultivars of maize plants harvested in the tasseling stage, and the lowest in maize plants of the Pyroxenia and Codmi cultivars harvested at the wax maturity stage.

\section{The organic matter digestibility (OM) of maize plants}

Statistical analysis demonstrated a significant influence of the experimental factors and their interaction of organic matter digestibility and dry matter digestibility (Tables 4 and 5).

Table 4. Organic matter digestibility (OM) of maize plants (means across 2009-2011), \%

\begin{tabular}{|c|c|c|c|c|}
\hline \multirow[t]{2}{*}{ Cultivars (B) } & \multicolumn{3}{|c|}{ Harvest date (A) } & \multirow[t]{2}{*}{ Means } \\
\hline & $\mathbf{I}$ & II & III & \\
\hline Pyroxenia & 53.63 & 66.49 & 71.65 & 63.92 \\
\hline Codami & 53.76 & 63.29 & 71.01 & 62.69 \\
\hline Moschus & 52.91 & 62.22 & 69.65 & 61.59 \\
\hline Alombo & 52.28 & 61.29 & 69.88 & 61.15 \\
\hline Celive & 53.88 & 61.87 & 70.34 & 62.03 \\
\hline Means & 53.29 & 63.03 & 70.51 & - \\
\hline$A N O V A$ & \multicolumn{2}{|c|}{ P-value } & \multicolumn{2}{|c|}{$\mathrm{LSD}_{0.05}$} \\
\hline Termin zbioru (A) & \multicolumn{2}{|c|}{$<0.001$} & \multicolumn{2}{|c|}{1.41} \\
\hline Odmiany (B) & \multicolumn{2}{|c|}{$<0.001$} & \multicolumn{2}{|c|}{1.84} \\
\hline Interaction (AxB) & \multicolumn{2}{|c|}{$<0.001$} & \multicolumn{2}{|c|}{2.73} \\
\hline
\end{tabular}

Table 5. Dry matter digestibility (DM) of maize plants (means across 2009-2011), \%

\begin{tabular}{|c|c|c|c|c|}
\hline \multirow{2}{*}{ Cultivars (B) } & \multicolumn{3}{|c|}{ Harvest date (A) } & \multirow{2}{*}{ Means } \\
\hline & I & II & III & \\
\hline Pyroxenia & 52.82 & 65.09 & 70.06 & 62.65 \\
\hline Codami & 53.47 & 61.83 & 69.52 & 61.61 \\
\hline Moschus & 52.54 & 60.62 & 67.95 & 60.37 \\
\hline Alombo & 51.70 & 59.82 & 68.11 & 59.88 \\
\hline Celive & 53.33 & 60.65 & 68.96 & 60.98 \\
\hline Means & 52.77 & 61.60 & 68.92 & - \\
\hline ANOVA & \multicolumn{2}{|c|}{$\mathrm{P}$-value } & \multicolumn{2}{|c|}{$\mathrm{LSD}_{0.05}$} \\
\hline Harvest date (A) & \multicolumn{2}{|c|}{$<0.001$} & \multicolumn{2}{|c|}{1.38} \\
\hline Cultivars (B) & \multicolumn{2}{|c|}{$<0.001$} & \multicolumn{2}{|c|}{1.77} \\
\hline Interaction (AxB) & \multicolumn{2}{|c|}{$<0.001$} & \multicolumn{2}{|c|}{2.63} \\
\hline
\end{tabular}

\section{The dry matter digestibility (DM) of maize plants}

The highest organic matter (OM) digestibility and dry matter (DM) digestibility were recorded for maize plants harvested at the wax maturity stage. Organic matter digestibility and dry matter digestibility of maize plants harvested at earlier development stages were significantly lower, the finding corresponding to reports by Michalski et al. (2002), Filya (2004), Yuxiang et al. (2007), Rodriges et al. (2008) and Swanckaert et al. (2017). In the present study, there was observed a significantly different response of the experimental cultivars in terms of both organic matter (OM) digestibility and dry matter (DM) digestibility, both kinds of digestibility being the highest for the earliest maturing cultivars, that is Pyroxenia and Codimi. Moreover, the dry matter (DM) digestibility of $\mathrm{cv}$. Celive, which is the latest maturing variety, differed insignificantly from DM digestibility of cv. Pyroxenia and Codimi. The organic matter 
(OM) digestibility and dry matter (DM) digestibility of cv. Moschus and Alombo were significantly lower. Also results of research by Tolera et al. (1999), Stejskalova et al. (2011) and Schttenhelm (2008) demonstrated cultivar-related differences between the organic matter digestibility and dry matter digestibility of both grain and green forage of maize plants representing other cultivars. Podkówka et al. (2015) reported that early maturing cultivars had a significantly higher organic substance (OS) digestibility of maize grain compared with medium early and late maturing cultivars. In the study reported here, an interaction between the experimental factors was found which is indicative of the fact that the highest organic matter (OM) digestibility and dry matter (DM) digestibility of all the experimental cultivars were recorded for plants harvested at the wax maturity stage, them being the lowest for cv. Pyroxenia, Codimi, Moschus, Alombo and Celive harvested at the tasseling stage.

\section{Summary}

Research on the suitability of cultivating new European cultivars from the Common Catalogue of varieties of Agricultural Plant Species (CCA) in soil and climatic conditions of Poland is fully justified. Therefore, it will be advisable to continuously study new cultivars in terms of dry matter yield and chemical composition of corn forage harvested in various development phases. This will allow the selection of such cultivars from the Common Catalogue of varieties of Agricultural Plant Species (CCA) useful for cultivation in Poland, which will be characterized by the highest yield and favorable chemical composition of forage, which will ensure good quality of silage.

\section{REFERENCES}

[1] Adamczyk, J. (2001): The importance of selecting varieties in the cultivation of maize for grain and silage. - Biul. Inf. IŻ - R. XXXIX 1: 29-35. (in Polish).

[2] Brzóska, F. (2001): Nutritional value of fodder from corn. - Biul. Inf. IŻ, R. XXXIX 1: 37-48. (in Polish).

[3] Filya, I. (2004): Nutritive value and aerobic stability of whole crop maize silage harvested at four stages of maturity. - Anim. Feed Sci. Tech. 116: 141-150.

[4] Jha, P. B., Ghosh, J., Nirala, R. B. P. (1998): Genetic variability and character association in fodder maize. - J. Res. Birsa Agric. Univ. 10(2): 139-143.

[5] Komainda, M., Taube, F., Klub, Ch., Antje, H. (2018): The effects of maize (Zea Mays L.) hybrid and harvest date on above-and belowground biomass dynamics, forage yield and quality - A trade-off for carbon inputs? - Eur. Jour. Agron. 92: 51-62.

[6] Korniewicz, A., Kosmala, I., Czarnik-Matusewicz, H., Paleczek, B. (2000): The contents of basic nutrients in the grain of different maize hybrids. - Rocz. Nauk Zoot. 27(1): 289303. (in Polish).

[7] Kowalik, I. (2001): Variability and correlation of elements of the maize yield structure (Zea mays L.) depending on weather conditions and nitrogen fertilization. - Rocz. AR Poznań, Rol. 61: 77-87. (in Polish).

[8] Lynch, J. P., O'Kiely, P., Doyle, E. M. (2012): Yield, quality and ensilage characteristics of whole-crop maize and of the cob and stover components: harvest date and hybrid effect. - Grass Forage Sci. 67(4): 472-487.

[9] Magalhäes, A., Rolim, M., Duarte, A., Pedrosa, E., Silva, E. (2015): Chemical attributes of soil and dry mass accumulation of maize fertilized with cassava wastewater. - Engen. Agric. 35(3): 458-469. 
[10] Michalski, T., Kruczyńska, H., Kowalik, I. (2002): Yields and quality of ensilaging maize depending on the cultivar and mowing height at harvested. - Acta Sci. Pol. Agric. 1(2): 83-92.

[11] Nawab, A., Anjum, M. M. (2017): Effect of Different Nitrogen Rates on Growth, Yield and Quality of Maize. - Mid. East Jour. Agric. Res. 06(1): 107-112.

[12] Podkówka, L., Podkówka, Z., Piwczyński, D., Buko, M. (2015): Effect of cultivar earliness on chemical composition and digestibility of maize grain. - Rocz. Nauk Zoot. 42(2): 155-169. (in Polish).

[13] Ptaszyńska, G., Sulewska, H. (2008): Yield variation of maize hybrids with different growing period in climatic conditions of central wielkopolska region. - Acta Sci. Pol. Agric. 7(3): 93-103. (in Polish).

[14] Rodrigues, A. M., Andueza, D., Picard, F., Cecato, U., Farruggi, A., Baumont, R. (2008): Classification of mountain permanent grasslands based on their feed value. - Biodiversity and animal. Grassland Sci. Europe. 13: 501-503.

[15] Schttenhelm, S. (2008): Chemical composition and methane field of maize hybrids with contrasting maturity. - Eur. Jour. Agron. 29(2-3): 72-78.

[16] Špaleková, A., Gálová, Z. (2018): Comparison of American and European maize (Zea mays L.) protein profiles. - J Cent Eur Agr. 19(2): 453-465.

[17] Stejskalova, M., Hejcmanova, P. Hejcman, M. (2013): Forage value of leaf fodder main European broad-leaved woody species. The role of grassland in a green future. - Grassl. Sci. Europe 18: 85-87.

[18] Strzetelski, A., Jurkiewicz, A., Strzetelski, J. (2001): Maize silage in cattle feed. - Biul. Inf. Inst. Zoot. 39(1): 49-62. (in Polish).

[19] Sulewska, H. (2001): Yielding and nutritive value of maize harvested on green mass depending on some agrotechnical factors. - Rocz. AR Poznań. Rozp. nauk. 315 (in Polish).

[20] Sulewska, H., Koziara, W. (2005): Influence of weather conditions on yielding and plant development of different maturity maize hybrids. - Sci. Pap. Agric. Univ. Poznań, Agric. 5: 35-41.

[21] Sulewska, H., Adamczyk, J., Rejek, D. (2011): Evaluation of the yield of new hybrids of fodder maize (Zea Mays L.) of Smolice Breeding. - Nauka Przy. Tech. 5(1): 1-11.

[22] Swanckaert, J., Pannecoucque, J., Van Waes, J., Cauwer, B., Latre, J., Haesaert, G., Reheul, D. (2016): Harvest date does not influence variety ranking in Belgian forage maize variety trials. - Jour. Agric. Sci. 154(6): 1040-1050.

[23] Szempliński, W., Bogucka, B., Wróbel, E. (2009): Suitability of early and mid-early maize hybrids grown in the province of Warmia and Mazury for silage production. - Acta Sci. Pol. Agric. 8(1): 57-68. (in Polish).

[24] Tolera, A., Sundstol, F., Said, A. N. (1998): The effect of stage of maturity on yield and quality of maize grain and stover. - Anim. Feed Sci. Tech. 75(2): 157-168.

[25] Tolera, A., Berg, T. Sundstol, F. (1999): The effect of variety on maize grain and crop residue yield and nutritive value of the stover. - Anim. Feed Sci. Technol. 79(3): 165177.

[26] Yuxiang, Ch., Jing, Ch., Daowei, Z. (2007): Effect of harvest date on shearing force of maize stems. - In Liv. Sci. 111(1): 33-44. 